Doi (https://doi.org/10.33506/sl.v9i1.710)

\title{
Pengaruh Produk Domestik Regional Bruto Dan Pengeluaran Pembangunan Terhadap Kesempatan Kerja Di Kantor Pemerintahan Kabupaten Gowa
}

\author{
Rostini $^{1}$ Syahribulan ${ }^{2}$ Martasia $^{3}$ \\ Fakultas Ekonomi, Prodi Manajemen, Universitas Indonesia Timur, Indonesia \\ Email : rostinihasanuddin@gmail.com
}

\begin{abstract}
Abstrak
Peneltian ini bertujuan untuk mengetahui Pengaruh Produk Domestik Bruto dan Pengeluaran Pembangunan Terhadap KesempatanKerja Daerah Kabupaten Gowa. Jenis data yang digunakan adalah data sekunder yaitu data yang diperoleh dari instansi-instansi atau kantor-kantor yang ada hubungannya dengan penelitian ini.Data sekunder adalah data yang dikumpulkan secara tidak langsung dari yang bersangkutan atau dari sumbernya.Populasi dalam penelitian ini adalah pengeluaran pembangunan, produk domestik regional bruto dan kesempatan kerja di Kabupaten Gowa. Sampel penelitian ini adalah pengeluaran pembangunan, PDRB, dan kesempatan kerja di Kabupaten Gowa. Berdasarkan analisis yang telah dilakukan diperoleh hasil analisis yang menunjukkan bahwa variabel kesempatan kerja memiliki t-hitung sebesar 3.054 dan probabilitas sebesar 0,005 lebih kecil dari 0,05 sehingga dapat disimpulkan bahwa variabel PDRB dan PP secara bersamaan berpengaruh signifikan terhadap kesempatan kerja pada taraf $5 \%$. Nilai koefisien regresi sebesar 0,723 dari Produk Domestik Regional Bruto (PDRB) dan Pengeluaran Pembangunan dapat meningkatkan kesempatan kerja. Hal ini berarti bahwa apabila terjadi peningkatan $1 \%$ dari Produk Domestik Regional Bruto (PDRB) dan pengeluaran pembangunan memberikan kesempatan kerja sebesar $0.723 \%$. Sehingga peneliti memberi kesimpulan bahwa Produk Domestik Regional Bruto (PDRB) dan Pengeluaran Pembangunan secara signifikan berpengaruh terhadap kesempatan kerja di Kabupaten Gowa.
\end{abstract}

Kata Kunci : Produk Domestik Bruto, Pengeluaran Pembangunan,Kesempatan Kerja

\begin{abstract}
This research aims to determine the effect of gross domestic product and development expenditure on regional employment opportunities in Gowa Regency. The type of data used is secondary data that is data obtained from agencies or offices that are related to this research. Secondary data is data collected indirectly from the person concerned or from the source. The population in this study is development expenditure, gross regional domestic product and employment opportunities in Gowa Regency. The sample of this research is development expenditure, GRDP, and employment opportunities in Gowa Regency. Based on the analysis that has been obtained, the results of the analysis show that the employment opportunity variable has a t-count of 3,054 and a probability of 0.005 less than 0.05 so it can be concluded that the GRDP and PP variables simultaneously have a significant effect on employment at the 5\% level. Regression coefficient of 0.723 from the Gross Regional Domestic Product (GRDP) and Development Expenditures can increase employment opportunities. This means that if there is a 1\% increase in Gross Regional Domestic Product (GRDP) and development expenditure provides employment opportunities by $0.723 \%$. So the researchers concluded that the Gross Regional Domestic Product (GRDP) and Development Expenditures significantly affected employment opportunities in Gowa Regency.
\end{abstract}

Keywords : Gross Domestic Product, Development Expenditures, Employment Opportunities 
Pengaruh Produk Domestic Regional Bruto...

Rostini

PENDAHULUAN

Doi (https://doi.org/10.33506/sl.v9i1.710)

Pembangunan ekonomi di indonesia merupakan serangkaian usaha dalam suatu perekonomian untuk mengembangkan kegiatan ekonominya sehingga infrastruktur lebih bnyak tersedia, perusahaan semakin banyak dan semakin berkembang, taraf pendidikan semakin tinggi dan teknologi semakin meningkat. Sebagai implikasi dari perkembangan ini diharapkan kesempatan kerja akan bertambah, tingkat pendapatan meningkat, dan kemakmuran masyarakat menjadi semakin tinggi. Salah satu peran perencanaan adalah sebagai arahan bagi proses pembangunan untuk berjalan menuju tujuan yang ingin dicapai disamping itu sebagai tolak ukur keberhasilan proses pembangunan yang dilakukan, sedangkan pembangunan sendiri dapat diartikan sebagai upaya yang dilakukan untuk meningkatkan pertumbuhan (Produk Domestik Bruto) pada tingkat nasional atau (Produk Domestik Regional Bruto) pada tingkat daerah.(Produk Domestik Regional Bruto) pada Kabupaten Gowa digunakan untuk mengetahui pertumbuhan ekonomi dari tahun ketahun, sehingga arah perekonomian daerah akan lebih jelas. PDRB juga adalah indikator untuk mengatur sampai sejauh mana keberhasilan pemerintah untuk memnfaatkan sumber daya yang ada dan dapat digunakan sebagai perencanaan dan pengambilan keputusan yang salah satunya untuk meningkatkan kesempatan kerja.

Pengeluaran pembangunan yaitu pengeluaran yang digunakan untuk membiayai pembangunan di bidang ekonomi, sosial,umum dan yang bersifat menambah modal masyarakat dalam bentuk pembangunan baik prasarana fisik maupun nonfisik yang dilaksanakan dalam periode tertentu.

Dalam proses pembangunan ekonomi, pertumbuhan penduduk merupakan suatu dinamika penting. Hal ini disebabkan, pertambahan penduduk akan berpengaruh pada pola pembangunan masyarakat dimasa yang akan datang. Selain itu, pengembangan kualitas sumber daya manusia yang didukung dengan peningkatan produktivitas juga menjadi faktor penentu dalam pembangunan ekonomi khususnya pada sector ketenagakerjaan.

Pengeluaran pemerintah atau disebut juga belanja Negara terdiri atas anggaran belanja pemerintah pusat/daerah, dana perimbangan, dan otonomi khusus dan dana penyeimbang. Anggaran belanja pemerintah pusat/daerah dibedakan atas pengeluaran rutin pembangunan. Pemerintah akan melakukan pengeluaran belanja pembangunan sebagai langkah untuk menjalankan fungsi-funsinya. 
Pengaruh Produk Domestic Regional Bruto...

Rostini

Doi (https://doi.org/10.33506/sl.v9i1.710)

Belanja pengeluaran merupakan pengeluaran pemerintah untuk memenuhi kebutuhan pembangunan. Tujuan pengeluaran pembangunan salah satunya untuk meningkat kesejahteraan masyarakat. Kesejahteraan masyarakat dapat diwujudkan dengan pemenuhan kebutuhan dasar seperti kesehatan, pendidikan dan infrastruktur. Pemenuhan kebutuhan dasar akan meningkatkan kualitas sumber daya manusia. Sumber daya yang berkualitas akan mampu memberikan kontribusi dalam kemajuan teknologi yang lebih mutahir sehingga dapat meningkatkan efesiensi produksi.

Kabupaten Gowa selalu memberi berbagai kebijakan ekonomi yang digunakan untuk menumbuhkan produksi yang lebih sehingga dapat dirasakan manfaatnya oleh masyarakat luas. Oleh karena itu orientasi pemerataan seharusnya menjadi muara dari seluruh kegiatan perekonomian suatu daerah.Setiap tahapan dari pembangunan bertujuan untuk meningkatkan taraf hidup dan kesejahteraan seluruh masyarakat, serta meletakkan landasan yang kuat untuk tahapan pembangunan selanjutnya. Pertumbuhan PDRB yang paling sedikit 5\% diperkirakan dapat menciptakan kesempatan kerja yang memadai sekaligus meningkatkan produktivitas dan upah rill.

Pertumbuhan ekonomi dibawah target tersebut akan menyebabkan ketimpangan kesempatan kerja, penurunan dalam target upah riel dan banyaknya terjadi pengangguran baik didesa maupun dikota. Tersedianya lapangan kerja dan penyerapan tenaga kerja amat ditentukan oleh dua besaran yaitu tingkat pertumbuhan penduduk dan angkatan kerja di pihak lain. Menurut pandangan Keynes, kebijakan fiskal sangat penting untuk mengatasi pengangguran yang sangat relatif serius.Melalui kebijakan fiskal pengeluaran agregat dapat ditambah dan langkah ini dapat menaikkan pendapatan nasional dan tingkat penggunaan tenaga kerja. Pengeluaran agregat dapat lebih ditingkatkan lagi dengan cara menaikkan pengeluaran pemerintah untuk membeli barang dan jasa yang diperlukannya maupun untuk menambah investasi swasta.

Salah satu masalah utama dihadapi indonesia khususnya diKabupaten Gowa adalah mengenai kesempatan kerja. Meskipun masalah ini telah mendapat perhatian dari pemerintah dengan diusahakannya menciptakan kesempatan kerja, namun kenyataannya perekonomian indonesia sampai saat ini masih ditandai dengan surplus tenaga kerja yang cukup besar. Hal ini disebabkan karena peningkatan jumlah angkatan kerja yang meningkat secara proporsional dengan meningkatkan jumlah penduduk yang tidak dibarengi dengan perluasan 
Pengaruh Produk Domestic Regional Bruto...

Rostini

Doi (https://doi.org/10.33506/sl.v9i1.710) lapangan kerja. Dengan meningkatkan jumlah angkatan kerja yang tidak dibareng dengan lapangan pekerjaan maka akan menciptakan pengangguran.

Masalah kesempatan kerja merupakan salah satu masalah yang tentunya harus di cari jalan keluarnya, dan hal ini akan di usahakan pemecahannya secara nasional. Tujuan-tujuan yang berorientasi pada penyediaan lapangan kerja merupakan suatu definisi yang lebih luas dari pembangunan, yang meliputi berbagai kondisi hidup perorangan di samping pertumbuhan ekonomi. Perluasan kesempatan kerja sebagai cara terpenting untuk menyebarkan hasil-hasil pertumbuhan ekonomi di seluruh Indonesia (Wie, 1983). Kesadaran akan pentingnya perluasan kesempatan kerja harus terpatri dalam setiap kebijakan ekonomi, Oleh karena itu kesdaran ini merupakan konsekuensi dari desakan masalah pengangguran yang dalam masa mendatang akan semakin berat, mengingat laju pertumbuhan penduduk yang tinggi dan pertambahan angkatan kerja yang cepat.

Harapan dalam suatu perekonomian yaitu pengangguran dapat di tekan sekecil mungkin, sehingga sasaran pembangunan dapat terwujud dalam kenyataan. Secepatnya laju pertumbuhan penduduk di gowa menjadi arah yang dapat menghambat pembangunan ekonomi. Menghadapi kondisi seperti ini, perancanaan masalah penduduk harus menjadi perhatian yang kontinu dan mengambil peluang-peluang yang menjadi alat dalam merancang masalah kependudukan. Tingginya tingkat pertumbuhan penduduk, akan menjadi sumber daya yang potensial jika strategi yang mengarah padahal ini dapat mengenai sasaran yang tepat atau dengan kata lain jumlah penduduk yang besar (angkatan kerja) dapat tertampung dalam dunia usaha (peningkatan penduduk di barengi dengan perluasan kesempatan kerja). Menciptakan perluasan kesempatan kerja untuk menyerap angkatan kerja yang ada membutuhkan kursus yang kuat yang nantinya dapat menjadi rujukan dalam menetapkan kebijakan dengan adanya wacana yang berkembang tentang masalah pengangguran setidaknya mengelitik para pengambil kebijakan dalam mengusahakan pemecahannya dan begitu pula para ekonomi tentunya dapat memberikan sumbansi pemikran atau solusi yang tepat, karena masalah ini akan semakin besar apabila era globalisasi (AFTA, 2013).

Perluasan kesempatan kerja yang produktif akan meningkatkan produksi, pendapatan dan partisipasi masyarakat dalam pembangunan. Untuk itu, cara yang efektif ditempuh pemerintah adalah dengan mengarahkan kegiatan pembangunan kepada proyek-proyek padat karya. Salah satu yang mengarah pada strategi tersebut yaitu pengeluaran pembangunan dan belanja public (belanja modal).Pengeluaran ini merupakan bagian dari pembiayaan program 
Pengaruh Produk Domestic Regional Bruto...

Rostini

Doi (https://doi.org/10.33506/sl.v9i1.710) atau kegiatan yang bersifat investasi yang bertujuan menambah asset daerah. Untuk dapat memperluas kesempatan kerja dan meningkatkan pertumbuhan ekonomi, pemerintah perlu meningkatkan sumber pembiayaan pembangunan dan kemampuan pengelolaannya. Dalam hal ini, pengeluaran pemerintah yaitu pengeluaran pembangunan yang akan sekarang dikenal sebagai belanja publik khususnya belanja modal lebih ditingkatkan karena dapat mendorong PDRB dalam proses peningkatan pertumbuhan ekonomi. Kesempatan kerja itu timbul karena adanya investasi dan usaha untuk memperluas kesempatan kerja ditentukan oleh laju pertumbuhan investasi, laju pertumbuhan penduduk, dan angkatan kerja. Strategi pembangunan yang diterapkan juga akan mempengaruhi usaha perluasan kesempatan kerja. Strategi pembangunan dan sasaran tujuan nasional harus benar-benar memperhatikan aspek sumber daya manusia dalam memasuki lapangan kerja, orientasi untuk peningkatan GDP (Gross Domestic Product) harus terlebih dahulu diikuti oleh peningkatan kualitas pendidikan, kesehatan dan keterampilan yang memadai agar dalam pembangunan tersebut peningkatan GDP ( Gross Domestic Product) juga diikuti dengan peningkatan produktivitas kerja. Peneltian ini bertujuan untuk mengetahui Pengaruh Produk Domestik Bruto dan Pengeluaran Pembangunan Terhadap KesempatanKerja Daerah Kabupaten Gowa.

\section{METODE}

Jenis data yang digunakan adalah data sekunder yaitu data yang diperoleh dari instansi-instansi atau kantor-kantor yang ada hubungannya dengan penelitian ini. Populasi dalam penelitian ini adalah pengeluaran pembangunan, produk domestik regional bruto dan kesempatan kerja di Kabupaten Gowa. Sampelnya adalah pengeluaran pembangunan, PDRB, dan kesempatan kerja di Kabupaten Gowa tahun 2016-2017. Dalam penelitian ini teknik pengumpulan data yang digunakan adalah kepustakaan dan lapangan.Sedangkan metode analisis data menggunakan pengujian asumsi klasik, uji normalitas, uji multikolonieritas, dan Uji heteroskedatisitas. Metode yang di gunakan adalah analisis regresi linear berganda dengan menggunakan program apliksi SPSS (statistical package for the social sciences). Persamaan regresi linear berganda sebagai berikut :

$$
\mathrm{Y}=\beta_{0+} \beta_{1} X_{1}+\beta_{2} X_{2}+\varepsilon
$$

Keterangan : 
Pengaruh Produk Domestic Regional Bruto...

Rostini

$\mathrm{Y} \quad=$ Kesempatan Kerja

Doi (https://doi.org/10.33506/sl.v9i1.710)

$\mathrm{X}_{1}=$ Produk Domestik Bruto

$\mathrm{X}_{2} \quad=$ Pengeluaran Pembangunan

$\beta_{0} \quad=$ Konstanta merupakan nilai terikat yang dalam hal ini adalah $\mathrm{Y}$ pada saat variabel bebasnya adalah $0\left(\mathrm{X}_{1}\right.$ dan $\left.\mathrm{X}_{2}=0\right)$

$\beta_{1} \quad=$ Koefisien Regresi Multiple antara variabel bebas $\mathrm{X}_{1}$ terhadap variabel terikat $\mathrm{Y}$, bila variabel bebas lainnya dianggap konstan.

$\boldsymbol{\varepsilon} \quad=$ Faktor Penggangu Di Luar model (Eror)

\section{Pengujian hipotesis}

Uji statistik F pada dasarnya menunjukkan apakah semua variable independen yang di masukkan dalam model mempunyai pengaruh bersama-sama, terhadap variable dependen (Ghozali,2011). Apabila pada derajat kepercayaan 5\%, nilai F hitung < Ftable atau nilai signufikan < 0,05 maka dapat di nyatakan bahwa semua variable dependen, proses penguji hipotesis untuk uji $\mathrm{F}$ adalah sebagai berikut : Tarif signifikan (a) 5\% atau 0,05\%. Kriteria pengujian sebagai berikut : a) jika $\mathrm{F}$ di hitung $<\mathrm{F}$ table , maka Ho di terimah atau Ha di tolak. b) jika F di hitung < F table maka Ha di terimah maka ho di tolak.

\section{HASIL DAN PEMBAHASAN}

Pembangunan ekonomi Kabupaten Gowa dari tahun ke tahun semakin membaik. Keadaan ini dapat dilihat dari angka PDRB atas dasar harga berlaku yang meningkat setiap tahunnya. Pada 2012 misalnya, nilai yang diperoleh sebesar 9,38 triliun rupiah dan tahun 2017 telah mencapai 17,27 triliun rupiah. PDRB Kabupaten Gowa atas dasar harga berlaku tahun 2013 sampai tahun 2017 dapat dilihat pada tabel 1 di bawah ini.

Tabel 1 Produk Domestik Regional Bruto dan Angka Perkapita Atas Dasar Harga Berlaku di Kabupaten Gowa, 2013 - 2017

\begin{tabular}{cccc}
\hline Tahun & $\begin{array}{c}\text { PDRB ADHB } \\
\text { ( Juta Rupiah) }\end{array}$ & $\begin{array}{c}\text { Penduduk } \\
\text { ( Jiwa })\end{array}$ & $\begin{array}{c}\text { PDRB Per Kapita } \\
\text { ( Juta Rupiah }) \\
(\mathbf{3})\end{array}$ \\
\hline 2013 & $\mathbf{( 2 )}$ & 696.096 & 15,39 \\
2014 & $10.713 .900,0$ & 709.386 & 16,98 \\
2015 & $12.044 .433,4$ & 722.702 & 19,03 \\
\hline
\end{tabular}




\begin{tabular}{|c|c|c|}
\hline & & $\begin{array}{r}\text { Pengaruh Produk Domestic Regional Bruto... } \\
\text { Rostini } \\
\text { Doi (https://doi.org/10.33506/sl.v9i1.710) }\end{array}$ \\
\hline 2016 & $15.524 .364,5$ & $735.493 \quad 21,11$ \\
\hline 2017 & 17.271.382,6 & 748.200 \\
\hline
\end{tabular}

Sumber : Kabupaten Gowa dalam Angka 2019

Salah satu indikator penting yang digunakan untuk mengamati hasil-hasil pembangunan ekonomi adalah pertumbuhan ekonomi. Indikator ini digunakan untuk mengukur tingkat pertumbuhan output dalam suatu perekonomian. Pertumbuhan ekonomi ini dapat dilihat dari besarnya nilai PDRB yang berhasil diciptakan pada tahun tertentu dibandingkan dengan nilai PDRB tahun sebelumnya. Nilai PDRB yang dibandingkan itu adalah nilai PDRB atas dasar harga konstan. Penggunaan nilai atas dasar harga konstan dimaksudkan untuk menghindari pengaruh perubahan harga. Dengan demikian angka pertumbuhan yang diperoleh semata-mata mencerminkan pertumbuhan PDRB riil yang dihasilkan oleh aktivitas perekonomian suatu wilayah pada periode tertentu.

\section{Tabel 2 PDRB Kabupaten Gowa Atas Dasar Harga Berlaku dan Atas Dasar Harga Konstan Tahun 2013-2017}

\begin{tabular}{cccc}
\hline Tahun & $\begin{array}{c}\text { PDRB ADH Berlaku } \\
\text { ( Juta Rupiah })\end{array}$ & $\begin{array}{c}\text { PDRB ADH } \\
\text { Konstan } \\
\text { ( Juta Rupiah })\end{array}$ & $\begin{array}{c}\text { Pertumbuhan } \\
\text { Ekonomi } \\
(\mathbf{\%})\end{array}$ \\
$\mathbf{( 1 )}$ & $(\mathbf{2})$ & $\mathbf{( 3 )}$ & $\mathbf{4})$ \\
\hline 2013 & $10.713 .900,0$ & $9.070 .002,2$ & 9,42 \\
2014 & $12.044 .433,4$ & $9.720 .169,6$ & 7,17 \\
2015 & $13.752 .439,4$ & $10.380 .218,7$ & 6,79 \\
2016 & $15.524 .364,5$ & $11.169 .730,1$ & 7,61 \\
2017 & $17.271 .382,6$ & $11.977 .299,6$ & 7,23
\end{tabular}

Sumber : Kabupaten Gowa dalam Angka 2019

Secara umum, PDRB atas dasar harga konstan 2013 terus mengalami peningkatan. Pada tahun 2017, PDRB atas dasar harga konstan 2013 sebesar 11,98 triliun rupiah. Namun, pertumbuhan ekonomi Kabupaten Gowa berfluktuasi dari tahun 2013 sampai tahun 2017. Pertumbuhan ekonomi meningkat dari tahun 2013 hingga tahun 2014, tetapi pada tahun 2015 dan 2016 pertumbuhan ekonomi turun menjadi 7,17 persen dan 6,79 persen. Pada tahun 2017, pertumbuhan ekonomi kembali menguat menjadi sebesar 7,63 persen. Namun pada tahun 2017, pertumbuhan ekonomi menurun kembali menjadi 7,23 persen. 
Pengaruh Produk Domestic Regional Bruto...

\section{Struktur Ekonomi}

Doi (https://doi.org/10.33506/sl.v9i1.710)

Salah satu kegunaan dari angka PDRB adalah untuk mengetahui struktur perekonomian suatu wilayah. Dengan analisis struktur ekonomi ini dapat diketahui besarnya persentase atau kontribusi setiap sektor terhadap pembentukan PDRB suatu wilayah pada tahun tertentu. Struktur ekonomi dapat mempunyai pengertian yang dinamis apabila struktur ekonomi tersebut tidak dibatasi pada suatu tahun tertentu saja melainkan dalam suatu rangkaian waktu (data series) sehingga dapat dilihat proses pergeseran struktur ekonomi di wilayah tersebut. Struktur ekonomi Kabupaten Gowa sebagian besar berada pada lapangan usaha pertanian, kehutanan, dan perikanan. Kontribusi lapangan usaha pertanian, kehutanan, dan perikanan terhadap perekonomian Kabupaten Gowa sebesar 30 persen pada tahun 2017. Meskipun kontribusi lapangan usaha ini cukup besar, tetapi dari tahun ke tahun kontribusinya terus menurun. Hal ini menunjukkan adanya pergeseran struktur ekonomi di Kabupaten Gowa. Pergeseran struktur ekonomi Kabupaten Gowa dari sektor primer menuju sektor sekunder dan sektor tersier.

\section{PDRB Perkapita}

PDRB perkapita merupakan angka yang dapat dibaca sebagai kemampuan daya beli masyarakat. Perekonomian yang membaik dan laju pertumbuhan penduduk yang melambat akan berdampak pada peningkatan PDRB perkapita. Namun, angka tersebut belum menggambarkan penerimaan penduduk secara nyata karena angka itu hanya merupakan angka rata-rata. Walaupun demikian, angka tersebut sudah dapat digunakan sebagai salah satu indikator untuk melihat rata-rata tingkat kesejahteraan penduduk suatu daerah.

Tabel 3 PDRB Perkapita Kabupaten Gowa dan Proyeksi Jumlah Penduduk Tahun 2013-2017

\begin{tabular}{ccccc}
\hline Tahun & $\begin{array}{c}\text { PDRB Perkapita } \\
\text { Kabupaten Gowa } \\
\text { ( Juta Rupiah ) }\end{array}$ & $\begin{array}{c}\text { Pertumbuhan } \\
\text { PDRB } \\
\text { Perkapita ( \% ) }\end{array}$ & $\begin{array}{c}\text { Proyeksi } \\
\text { Jumlah } \\
\text { Penduduk } \\
\text { ( Jiwa })\end{array}$ & $\begin{array}{c}\text { Pertumbuhan } \\
\text { Penduduk } \\
\mathbf{( \% )}\end{array}$ \\
$\mathbf{( 1 )}$ & $\mathbf{( 2 )}$ & $\mathbf{( 3 )}$ & 696.096 & $\mathbf{( 5 )}$ \\
\hline 2013 & 15,39 & 12,01 & 709.386 & 1,97 \\
2014 & 16,98 & 10,33 & 722.702 & 1,88 \\
2015 & 19,03 & 12,07 & 735.493 & 1,77 \\
\hline 2016 & 21,08 & 10,77 & & \\
\hline
\end{tabular}


Pengaruh Produk Domestic Regional Bruto...

Rostini

Doi (https://doi.org/10.33506/s1.v9i1.710)

$\begin{array}{lllll}2017 & 23,08 & 9,49 & 748.200 & 1,73\end{array}$

Sumber : Kabupaten Gowa dalam Angka 2019

PDRB Per kapita Kabupaten Gowa dari tahun 2013 sampai tahun 2017 terus mengalami peningkatan. Pada tahun 2017 PDRB per kapita Kabupaten Gowa sebesar 23,08 juta rupiah. Di sisi lain, pertumbuhan PDRB per kapita Kabupaten Gowa dari tahun 2013 sampai tahun 2014 mengalami perlambatan. Lain halnya dengan tahun 2015 yang meningkat menjadi 12,07 persen dibandingkan pada tahun 2014. Peningkatan pertumbuhan PDRB per kapita dikarenakan oleh pertumbuhan PDRB Kabupaten Gowa yang lebih tinggi dibandingkan dengan pertumbuhan jumlah penduduk. Pada tahun 2017, PDRB per kapita Kabupaten Gowa kembali melambat menjadi 9,49 persen. Hal ini mengindikasikan bahwa pertumbuhan PDRB Kabupaten Gowa yang lebih lambat dibandingkan dengan pertumbuhan jumlah penduduk. Untuk lebih jelasnya lihat gambar 1 berikut ini.

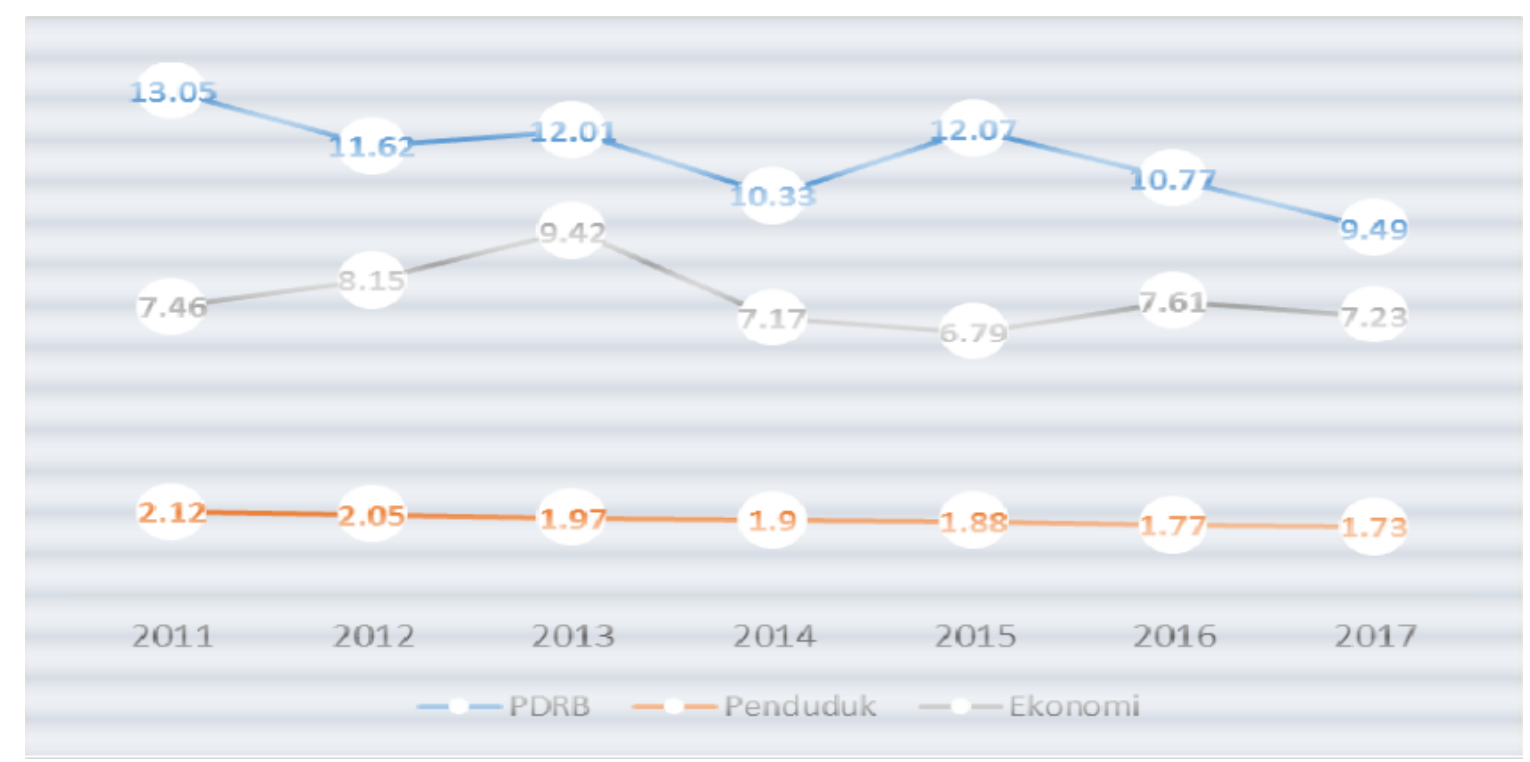

Sumber : Kabupaten Gowa dalam Angka 2019

Gambar 1 Pertumbuhan Ekonomi, Pertumbuhan Penduduk, dan Pertumbuhan PDRB Per Kapita di Kabupaten Gowa Tahun 2013-2017

\section{Uji Autokorelasi}

Uji autokorelasi adalah sebuh uji yang bertujuan untuk mengatahui ada tidaknya korelasi antar variabel. Uji autokorelasi bertujuan untuk mengguji apakah dalam model regresi linier ada korelasi antara kesalahan pengganggu pada periode t dengan kesalahan 
Pengaruh Produk Domestic Regional Bruto...

Rostini

Doi (https://doi.org/10.33506/sl.v9i1.710) pada periode t-1 (sebelumnya). Untuk mendeteksi ada tidaknya masalah tersebut maka apat dilihat melalui uji Durbin-Watson (DW).

Tabel 4 Hasil Uji Autokorelasi Durbin Watson

\section{Change Statistics}

\begin{tabular}{cccccc} 
R Square Change & F Change & df1 & df2 & $\begin{array}{c}\text { Sig. F } \\
\text { Change }\end{array}$ & Durbin-Watson \\
\hline .523 & 1.094 & 2 & 2 & .477 & 1.826
\end{tabular}

Sumber : Hasil Pengolahan Data 2019

Pada tabel 4 hasil uji yang dilaksanakan, diperoleh nilai Durbin Watson sebesarr 1.826 dengan nilai $\mathrm{dL}=0.61018$ dan nilai $\mathrm{dU}=1,40015$. Sehingga nilai $\mathrm{d}$ hitung berada pada kriteria $\mathrm{d}>2$ dan 4-d > dU maka dapat disimpulkan bahwa tidak ada autokorelasi.

\section{Uji Multikolinearitas}

Uji multikolinearitas bertujuan untuk menguji apakah model regresi ditemukan adanya korelasi antar variabel bebas atau variabel independen. Model regresi yang baik seharusnya tidak terjadi korelasi diantara variabel independen. Sebaliknya, koefisien korelasi kurang dari 0,8 maka model bebas dari multikolinearitas. Berikut adalah tabel hasil uji multikolinearitas.

Tabel 5 Hasil Uji Multikolinearitas

\begin{tabular}{lccc}
\hline Variabel & $\begin{array}{c}\text { Kesempatan } \\
\text { Kerja }\end{array}$ & $\begin{array}{c}\text { Pengeluaran } \\
\text { Pembangunan }\end{array}$ & Keterangan \\
\hline KS & 1 & 0,602 & Tidak terjadi mutikolinearitas \\
PDRB & 0,602 & 1 & Tidak terjadi mutikolinearitas \\
PP & 0.500 & 1 & Tidak terjadi mutikolinearitas \\
\hline
\end{tabular}

Sumber : Hasil Pengolahan Data 2019

Berdasarkan tabel 5 hasil uji multikolinearitas yang telah dilakukan di atas, seluruh koefisien korelasi kurang dari 0,8. Oleh karena itu, dapat disimpulkan bahwa tidak terdapat multikolinearitas anatar variabel independen.

Koefisien Determinasi (R2) 
Pengaruh Produk Domestic Regional Bruto...

Rostini

Doi (https://doi.org/10.33506/sl.v9i1.710)

Koefisien determinasi ini mengukur seberapa jauh kemampuan model dalam menerangkan variasi variabel dependen atau disebut pula dengan uji goodness of fit. Nilai koefisien determinasi adalah antara nol dan satu. Oleh karena itu, pada penelitian ini menggunakan koefisien determinasi yang disesuaikan (adjusted R2).

Tabel 6 Hasil Uji Koefisien Determinasi

\begin{tabular}{lc}
\hline R-squared & 0,523 \\
\hline Adjusted R-squared & 0,450
\end{tabular}

Sumber : Hasil Pengolahan Data 2019

Berdasarkan tabel 6, adjusted R2 sebesar 0,517457. Hal ini berarti kontribusi seluruh variabel independen dalam menjelaskan variabel dependen sebesar $52.3 \%$. Sisanya 47.7\% dijelaskan oleh variabel lain di luar model.

\section{Uji Statistik t}

Uji statistik $\mathrm{t}$ dilakukan untuk mengetahui apakah variabel independen secara individu mempeengaruhi variabel dependen. Berdasarkan hasil uji statistik t kedua variabel independen secara individu berpengaruh signifikan terhadap variabel dependen. Adapun hasil uji t Pengaruh PDRB dan PP terhadap Kesempatan Kerja dapat dilihat pada tabel berikut:

\section{Tabel 7 Hasil Uji T}

\begin{tabular}{|c|c|c|c|c|c|c|}
\hline & \multirow[b]{2}{*}{ Model } & \multicolumn{2}{|c|}{$\begin{array}{l}\text { Unstandardized } \\
\text { Coefficients }\end{array}$} & \multirow{2}{*}{$\begin{array}{c}\begin{array}{c}\text { Standardized } \\
\text { Coefficients }\end{array} \\
\text { Beta }\end{array}$} & \multirow[b]{2}{*}{$\mathbf{t}$} & \multirow[b]{2}{*}{ Sig. } \\
\hline & & B & Std. Error & & & \\
\hline \multirow[t]{3}{*}{1} & (Constant) & 1515.413 & 496.150 & & 3.054 & .005 \\
\hline & PDBP & -.358 & .452 & -.416 & -.791 & .487 \\
\hline & PP & -570 & .721 & -.546 & -987 & .766 \\
\hline
\end{tabular}

Sumber : Hasil Pengolahan Data 2019

Pada tabel 7 hasil analisis menunjukkan bahwa variabel kesempatan kerja memiliki t-hitung sebesar 3.054 dan probabilitas sebesar 0,005 lebih kecil dari 0,05 sehingga dapat 
Pengaruh Produk Domestic Regional Bruto...

Rostini

Doi (https://doi.org/10.33506/sl.v9i1.710)

disimpulkan bahwa variabel PDRB dan PP secara bersamaan berpengaruh signifikan terhadap kesempatan kerja pada taraf 5\%. Nilai koefisien regresi sebesar 0,723 menunjukkan bahwa PDRB dan PP berpengaruh positif terhadap kesempatan kerja di Kabupaten Gowa. Dengan demikian dapat hasil uji t variabel PDRB dan PP berpengaruh positif terhadap kesempatan kerja di Kabupaten Gowa.

\section{Uji Statistik F}

Tabel 8 Hasil Uji F

\begin{tabular}{llccccc}
\hline & Model & $\begin{array}{c}\text { Sum of } \\
\text { Squares }\end{array}$ & Df & Mean Square & F & Sig. \\
\hline 1 & Regression & 19057.430 & 2 & 9528.715 & 22.094 & $.000^{\mathrm{a}}$ \\
& Residual & 17415.770 & 2 & 8707.885 & & \\
& Total & 36473.200 & 4 & & & \\
\hline
\end{tabular}

Sumber : Hasil Pengolahan Data 2019

Berdasarkan tabel 8 hasil analisis yang telah dilakukan diperoleh nilai $\mathrm{F}$ hitung sebesar 22.094 dengan probabilitas sebesar 0,00. Nilai probabilitas tersebut lebih kecil dari 0,05, sehingga dapat disimpulkan bahwa semua variabel independen secara bersama-sama berpengaruh signifikan terhadap variabel dependen. Dengan demikian PDRB dan PP berpengaruh secara bersama-sama berpengaruh siginifikan terhadap kesempatan kerja di Kabupaten Gowa. Analisis data panel dalam penelitian ini bertujuan untuk mengetahui pengaruh PDRB dan PP terhadap Kesempatan Kerja di Kabupaten Gowa. PDRB menunjukkan tingkat kemakmuran suatu daerah. PDRB adalah jumlah nilai tambah bruto yang dihasilkan seluruh unit usaha dalam wilayah tertentu, atau merupakan jumlah nilai barang dan jasa akhir yang dihasilkan oleh seluruh unit ekonomi.

Pada hasil penelitian ini diperoleh nilai koefisien regresi sebesar 0,723 menunjukkan bahwa PDRB dan PP berpengaruh positif terhadap kesempatan kerja di Kabupaten Gowa. Berdasarkan hasil analisis yang telah dilakukan, variabel PDRB dan PP secara individu berpengaruh signifikan terhadap kesempatan kerja. Dapat diatan bahwa esempatan kerja tergantung pada ketersediaan faktor-faktor produksi domestik bruto, pengeluaran 
Pengaruh Produk Domestic Regional Bruto...

Rostini

Doi (https://doi.org/10.33506/sl.v9i1.710) pembangunan pertumbuhan ekonomi dan kesejahteraan masyarakat. Oleh karena itu faktor PDRB berpengaruh terhadap kesempatan kerja dan laju pertumbuhan ekonomi.

Berdasarkan hasil pengujian variabel Produk Domestik Regional Bruto dan Pengeluaran Pembangunan secara bersama berpengaruh terhadap kesempatan kerja di Kabupaten Gowa. Dalam konsep ekonomi makro penegluaran pembangunan akan meningkatkan perekonomian nasional. Jadi apabila pengeluaran pembangunan meningkat maka akan menyebabkan pertumbuhan ekonomi meningkat. Berdasarkan persamaan regresi diatas, dapat dilihat nilai koefisien regresi sebesar 0,723. Hal ini berarti apabila terjadi peningkatan jumlah Pengeluaran Pembangunan sebesar 1\% maka akan menyebabkan peningkatan terhadap Pertumbuhan Ekonomi sebesar 0.723\%. Dalam model makroekonomi yang dikembangkan oleh Keynes, peningkatan PDRB dipengaruhi oleh kenaikan konsumsi, investasi, pengeluaran pemerintah dan net ekspor.

Peningkatan pengeluaran pemerintah terjadi seiring dengan peningkatan kegiatan perekomian. Pengeluaran pemerintah dalam penenlitian ini adalah seluruh belanja daerah baik belanja langsung maupun belanja tidak langsung. Dengan meningkatnya pengeluaran pemerintah maka akan mempengaruhi konsumsi yang terjadi di masyarakat. Selain itu pengeluaran pemerintah dalam bidang kesehatan maupun pendidikan juga mempengaruhi peningkatan produktivitas yang berdampak pada peningkatan output produksi, sehingga mampu meningkatkan pertumbuhan ekonomi daerah.

\section{SIMPULAN}

Hasil analisis yang telah dilakukan menunjukkan bahwa variabel kesempatan kerja memiliki t-hitung sebesar 3.054 dan probabilitas sebesar 0,005 lebih kecil dari 0,05 sehingga dapat disimpulkan bahwa variabel PDRB dan PP secara bersamaan berpengaruh signifikan terhadap kesempatan kerja pada taraf 5\%. Nilai koefisien regresi sebesar 0,723 dari Produk Domestik Regional Bruto (PDRB) dan Pengeluaran Pembangunan dapat meningkatkan kesempatan kerja. Hal ini berarti bahwa apabila terjadi peningkatan $1 \%$ dari Produk Domestik Regional Bruto (PDRB) dan pengeluaran pembangunan memberikan kesempatan kerja sebesar $0.723 \%$. Sehingga peneliti memberi kesimpulan bahwa Produk Domestik Regional Bruto (PDRB) dan Pengeluaran Pembangunan secara signifikan berpengaruh terhadap kesempatan kerja di Kabupaten Gowa. 
Pengaruh Produk Domestic Regional Bruto...

Rostini

Doi (https://doi.org/10.33506/sl.v9i1.710)

\section{UCAPAN TERIMA KASIH}

Ucapan terimakasih peneliti sampaikan kepada Kepala Kantor Pemerintahan Kabupaten Gowa dan segenap jajarannya atas bantuan yang diberikan kepada peneliti sehingga penelitian ini dapat berjalan sebagaimana mestinya, ucapan yang sama juga penulis sampaikan kepada pihak Universitas Indonesia Timur (UIT) Makassar yang telah memfasilitasi, memberikan bantuan moril maupun meteril kepada penulis.

\section{DAFTAR PUSTAKA}

Badan Pusat Statistik. 2015. Indikator Ekonomi Sulawesi Selatan

Bagus, Santa, Wardana. Faktor-Faktor Yang Mempengaruhi Pertumbuhan

Ekonomi Dan Dampaknya Terhadap Kesempatan Kerja, 1990, Bisnis Udayana. Hal, 134

Dumairy. 1997, Perekonomian Indonesia. Penerbit : Erlangga, Jakarta

Djoyohadikusuma, Sumitro. 1994. Dasar Teori Ekonomi Pertumbuhan Dan Ekonomi Pembangunan(Perkembangan Pemikiran Ekonomi. LP3ES, Jakarta

H. Faisal, Basri. 2002. Perekonomian Indonesia. Jakarta: Erlangga.

Jaka, Sriyana dan Fitri, Rosyidah.2007. Pengaruh Pengeluaran Pembangunan

Terhadap Perekonomian. Indonesia, Yogyakarta. Unisia, Vol.30, Hal, 195

Jhingan, ML. 1988, Ekonomi Pembangunan dan Perencanaan. Cetakan Pertama, Jakarta, CV. Rajawali

Lailan, Safina. 2011, Analisis Pengaruh Investasi Pemerintah Dan Swasta

Terhadap Penciptaan Kesempatan Kerja. Sumatera, Manajemen dan bisnis. Vol, 11.No. 01, Hal, 3-4

Naomi, Octalia. Sembiring, 2015. Analisis Permintaan Tenaga Kerja, Penogoro.Industri, Manufaktur. Hal, 27-28

Suroto, Drs, MA. 1986, Strategi Pembangunan dan Perencanaan Tenaga Kerja. Gajah Mada Universitas Press. Yogyakarta 